\title{
Method for the Determination of Benzene Metabolite $t, t$-Muconic Acid in Urine by HPLC-UV with an Ion Exclusion Column
}

\author{
Rafaela de Paiva Gomes, Ananda Lima Sanson, Fabiana Aparecida Lobo, \\ Robson José de Cássia Franco Afonso and Mauricio Xavier Coutrim * \\ Department of Chemistry, Institute of Exact and Biological Sciences, Federal University of Ouro Preto, \\ Campus Morro do Cruzeiro, s/n, Bauxita, 35400-000 Ouro Preto, MG, Brazil; \\ rafaela_p_gomes@hotmail.com (R.P.G.); ananda_lima@hotmail.com (A.L.S.); fabiana@iceb.ufop.br (F.A.L.); \\ robsonafonso@iceb.ufop.br (R.J.C.F.A.) \\ * Correspondence: mcoutrim@iceb.ufop.br; Tel.: +55-31-3559-1713; Fax: +55-31-3559-1707 \\ Academic Editor: Frank L. Dorman \\ Received: 14 December 2015; Accepted: 26 April 2016; Published: 13 May 2016
}

\begin{abstract}
The benzene metabolite trans,trans-muconic acid ( $t$-MA) is widely used as a biological indicator of exposure to this xenobiotic. An analytical method was developed and validated for the determination of urinary $t t$-MA using solid phase extraction onto a Strata SAX cartridge. The analysis was performed by HPLC with an Aminex HPX-87H ion exclusion column and a UV diode array detector. The sample preparation conditions were optimized using a $2^{4-1}$ factorial design. Comparison of the slopes of standard analytical curves prepared in aqueous solution and urine showed that the biological matrix suppressed the $t t$-MA signal by around $50 \%$, so the analytical curves were prepared with $t$-MA standard at low concentrations in pooled urine. The analytical curves in the range of $5-500 \mu \mathrm{g} \cdot \mathrm{L}^{-1}$ showed determination coefficients values $\left(R^{2}\right)>0.99$ for $t t$-MA standard in water and $R^{2}>0.98$ for $t t$-MA standards in pooled urine. The coefficients of variation obtained using seven replicates were lower than $3.6 \%$, and recoveries of $t t$-MA from solutions containing $5,25,50$ and $100 \mu \mathrm{g} \cdot \mathrm{L}^{-1}$ of the analyte were in the range $85 \%-90 \%$, demonstrating the satisfactory precision and accuracy of the method. The limits of detection and quantification were 0.11 and $0.36 \mu \mathrm{g} \cdot \mathrm{L}^{-1}$, respectively. The benefits of this new method developed is the possibility of complete chromatographic peak separation for the determination of $t t$-MA at baseline, without matrix components' interference as normally found in the C18 column. This is the first time that this chromatographic column has been used for the analysis of $t t-\mathrm{MA}$ in urine.
\end{abstract}

Keywords: benzene; trans,trans-muconic acid; exposure biomarker; environmental exposure; Aminex HPX-87H ion exclusion column

\section{Introduction}

Despite substantial progress over the last 20 years in understanding the risks posed by benzene, there is a continuing need for the development of sensitive techniques able to determine the compound at low levels, in order to assist in the implementation of control strategies. Various methods have been reported for the evaluation of the contamination of humans by benzene. These normally measure benzene in its original form and have been applied to exhaled air [1-4], blood [4-7] and urine [6,8-10]. However, various difficulties have been described, related to problems in sample preparation (for air samples), the small fraction of benzene that remains unaltered (in urine) and invasive sample collection (of blood). An alternative to the evaluation of exposure to benzene by directly measuring its concentration in air is to determine the concentrations of its metabolites in urine or blood that involve the use of biological exposure indicators (BEIs). Two of the metabolites of benzene that can 
be used as a BEI are trans,trans-muconic acid (tt-MA) and S-phenyl mercapturic acid (SPMA), which are biomarkers that are more sensitive and specific, compared to urinary phenol [11]. This exposure biomarker has therefore been adopted in Brazilian legislation for the monitoring of occupational exposure to benzene [12]. The widespread use of $t t$-MA as a BEI is due to the good correlation obtained between the level of the compound in urine and the concentrations of benzene in air and blood, even after exposure to low concentrations of benzene.

Various techniques have been developed for the determination of $t t$-MA in urine. The most widely-used sample preparation procedure employs solid phase extraction (SPE) with ion exchange resins [13-18]. This procedure reduces the quantities of solvents required and provides better recoveries, as well as clearer extracts, compared to the non-extraction procedure [19,20].

Only a few studies have employed gas chromatography for the determination of urinary $t t-M A$ [21-25]. On the other hand, there has been widespread use of high performance liquid chromatography (HPLC) with reverse phase columns and ultraviolet and visible spectrophotometry (UV-VIS) or mass spectrometry (MS) detection [26-42]. One way to separate anions by chromatography is to use cation exchange columns where the ions are separated by ion exclusion. In this type of chromatography, the analytical conditions allow that part of the mobile phase to remain immobilized in the stationary phase, and the separation is due to the differences in the partitioning of the molecular solute between the solvent from the mobile phase and the solvent immobilized on the resin [43]. However, no analytical method has been described in the literature for the determination of urinary $t t$-MA as a BEI for benzene using HPLC with an Aminex HPX-87H column, although this analyte and other volatile organic acids have been determined in various other sample matrices using this type of column [44-46].

The objective of this work was to develop a new technique for the measurement of $t t$-MA in urine, using SPE (SAX cartridges) and HPLC with an Aminex HPX-87H column and UV detection.

\section{Experimental Section}

\subsection{Instruments and Accessories}

The extraction of $t t$-MA employed Strata SAX cartridges containing $500 \mathrm{mg}$ of trimethylaminopropylsilane (Phenomenex ${ }^{\circledR}$, Torrance, CA, USA), a manifold (Phenomenex ${ }^{\circledR}$ ) and a vacuum pump (Model 131, Prismatec Ind Com, Itu, SP, Brazil). Analysis was performed with an HPLC (Model 20A, Shimadzu, Columbia, MD, USA) equipped with a diode array. The column used was an Aminex HPX-87H (300 $\times 7.8$ mm, Bio-Rad Laboratories, Hercules, CA, USA), recommended for the separation of carboxylic acids, installed in a temperature-controlled oven (Model TC300, GBC Scientific Equipment Pty Ltd., Hamsphire, IL, USA), and the chromatograms were recorded at 264 nm using LabSolutions System software, version 5.53 SP3 (Shimadzu, Laval, Quebec, PQ, Canada). Additional items of equipment were micropipettes of various volumes, an analytical balance (Model AUY 220, Shimadzu) and a membrane filtration system (PTFE, $0.22-\mu \mathrm{m}$ pore size, Phenomenex ${ }^{\circledR}$ ).

\subsection{Reagents, Solutions and Samples}

The reagents used were methanol, acetic acid, acetonitrile and sulfuric acid, all chromatography grade (JT Baker ${ }^{\circledR}$, Center Valley, PA, USA), trans, trans-muconic acid (analytical grade, $99 \%$ min. purity, Sigma-Aldrich ${ }^{\circledR}$, St. Louis, MO, USA) and pH 8.0 tris-phosphate buffer (Sigma-Aldrich ${ }^{\circledR}$ ). The ultra-pure water (conductivity of $0.065 \mu \mathrm{S}$ ) was obtained from a LAB-UPW system (TKA, Niederelbert, Germany).

A standard solution of $t t-\mathrm{MA}\left(10 \mathrm{mg} \cdot \mathrm{L}^{-1}\right)$ was prepared in water and diluted to obtain standards at lower concentrations. Ten different urine samples were obtained from non-smoker volunteers ( 5 males and 5 females) and were combined to produce a pooled urine sample.

\subsection{Optimization of the Procedure}

A $2^{4-1}$ factorial design was used to define the sample preparation conditions. The chromatographic conditions were optimized in a univariate manner. 


\subsubsection{Preparation of Samples}

The sample cleanup procedure was based on the method described previously by Ducos et al. (1990) [27] and is illustrated in the flow diagram of Figure 1.

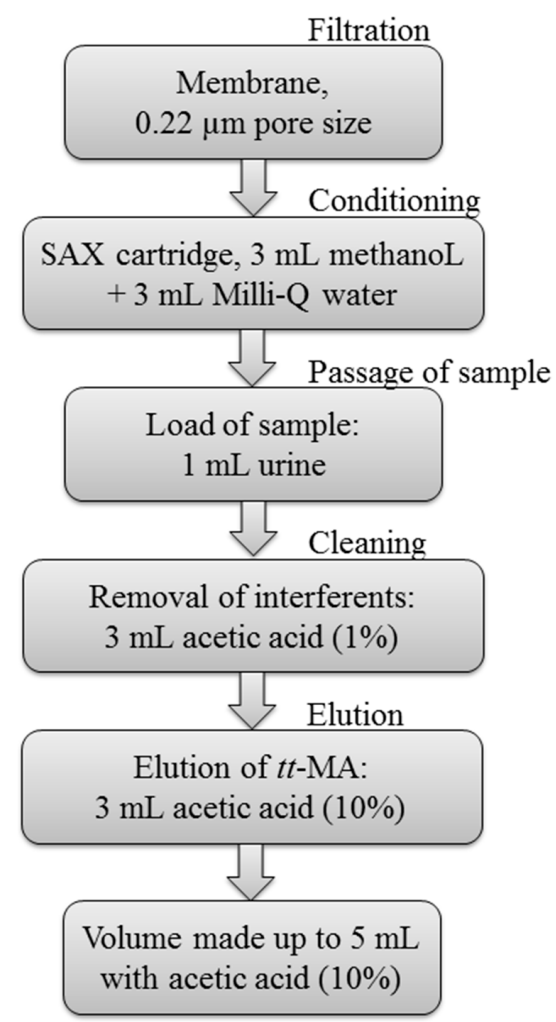

Figure 1. Flow diagram illustrating the sample cleanup procedure. $t$-MA, trans,trans-muconic acid.

The sample was filtered through a $0.22 \mu \mathrm{m}$ membrane, after which the $t t$-MA was extracted using a SAX cartridge. The extraction was performed under vacuum using a manifold with a capacity for 12 cartridges. The entire procedure was performed in triplicate.

\subsubsection{Optimization of the Sample Preparation Procedure}

A factorial design was used to evaluate the need for the buffering of the samples, as well as to adjust other factors related to sample transfer, cleanup and elution. An appropriate electronic spreadsheet was used for the preparation and interpretation of the experimental designs [47]. Four variables were investigated (sample buffering, removal of interferents (washing), final volume and sample volume), at three levels (Table 1).

Table 1. Variables and levels used in the $2^{4-1}$ fractional factorial design.

\begin{tabular}{cccc}
\hline \multirow{2}{*}{ Variable } & \multicolumn{3}{c}{ Level } \\
\cline { 2 - 4 } & $\mathbf{- 1}$ & $\mathbf{0}$ & $\mathbf{1}$ \\
\hline Solution buffering & No buffering & $\mathrm{pH} 8.0$ & $\mathrm{pH} 10.0$ \\
Removal of interferents (washing) & No addition of water & $1.5 \mathrm{~mL}$ of water & $3.0 \mathrm{~mL}$ of water \\
Final volume & $3.0 \mathrm{~mL}$ & $4.0 \mathrm{~mL}$ & $5.0 \mathrm{~mL}$ \\
Sample volume & $1.0 \mathrm{~mL}$ & $2.0 \mathrm{~mL}$ & $3.0 \mathrm{~mL}$ \\
\hline
\end{tabular}

The parameters shown in Table 1 were used to generate 11 experiments, as shown in Table 2. The experiments were performed in random order. Throughout the optimization procedure, the response was based on the analyte peak area. 
Table 2. Investigation of the experimental variables using a $2^{4-1}$ fractional factorial design with three replicates at the central point $(\mathrm{CP})$.

\begin{tabular}{|c|c|c|c|c|c|}
\hline Tests & Variable & Buffering of the Solution & Washing & Final Volume & Sample Volume \\
\hline & Test 1 & no buffering $(-1)$ & no water addition $(-1)$ & $3.0 \mathrm{~mL}(-1)$ & $1.0 \mathrm{~mL}(-1)$ \\
\hline & Test 2 & pH $10.0(1)$ & no water addition $(-1)$ & $3.0 \mathrm{~mL}(-1)$ & $3.0 \mathrm{~mL}(1)$ \\
\hline & Test 3 & no buffering $(-1)$ & $3.0 \mathrm{~mL}$ of water $(1)$ & $3.0 \mathrm{~mL}(-1)$ & $3.0 \mathrm{~mL}(1)$ \\
\hline & Test 4 & pH $10.0(1)$ & $3.0 \mathrm{~mL}$ of water $(1)$ & $3.0 \mathrm{~mL}(-1)$ & $1.0 \mathrm{~mL}(-1)$ \\
\hline & Test 5 & no buffering $(-1)$ & no water addition $(-1)$ & $5.0 \mathrm{~mL}(1)$ & $3.0 \mathrm{~mL}(1)$ \\
\hline & Test 6 & pH 10.0 (1) & no water addition $(-1)$ & $5.0 \mathrm{~mL}(1)$ & $1.0 \mathrm{~mL}(-1)$ \\
\hline & Test 7 & no buffering $(-1)$ & $3.0 \mathrm{~mL}$ of water $(1)$ & $5.0 \mathrm{~mL}(1)$ & $1.0 \mathrm{~mL}(-1)$ \\
\hline & Test 8 & pH 10.0 (1) & $3.0 \mathrm{~mL}$ of water $(1)$ & $5.0 \mathrm{~mL}(1)$ & $3.0 \mathrm{~mL}(1)$ \\
\hline & $\mathrm{CP} 1$ & $\mathrm{pH} 8.0(0)$ & $1.5 \mathrm{~mL}$ of water $(0)$ & $4.0 \mathrm{~mL}(0)$ & $2.0 \mathrm{~mL}(0)$ \\
\hline & $\mathrm{CP} 2$ & $\mathrm{pH} 8.0(0)$ & $1.5 \mathrm{~mL}$ of water $(0)$ & $4.0 \mathrm{~mL}(0)$ & $2.0 \mathrm{~mL}(0)$ \\
\hline & $\mathrm{CP} 3$ & $\mathrm{pH} 8.0(0)$ & $1.5 \mathrm{~mL}$ of water $(0)$ & $4.0 \mathrm{~mL}(0)$ & $2.0 \mathrm{~mL}(0)$ \\
\hline
\end{tabular}

Note: Level (1): highest value; Level (-1): lowest value; Level (0): central point (CP).

\subsubsection{Chromatographic Conditions}

Development of the new analytical method was initially based on the procedure described by Ducos et al. (1990) [27], with modifications in terms of the types of chromatographic precolumn and main column employed, as well as the mobile phase and the wavelength used to detect $t t$-MA. In this step of the work, the optimization of the variables was performed in a univariate manner. Nine chromatographic mobile phase compositions were tested, together with two different flow rates and the presence or absence of the precolumn.

\subsection{Validation of the Method}

The analytical method was validated considering the following parameters: selectivity, linearity, working range, limits of detection and quantification, precision and accuracy.

A comparison was made of analytical curves constructed using solutions prepared in water and in the sample matrix. In the case of the sample matrix, the curves employed the results obtained for standard solutions prepared by adding aliquots of $t t$-MA solutions to volumes of the pooled urine sample composed of the samples obtained from the ten non-smoker volunteers. The $t t$-MA solutions were prepared by fortification of the pooled urine with an intermediate standard solution obtained by dilution of the $10 \mathrm{mg} \cdot \mathrm{L}^{-1}$ solution of $t t-\mathrm{MA}$ in water.

The standards prepared in the sample matrix were subsequently submitted to the same treatment employed for the samples: filtration through a $0.22 \mu \mathrm{m}$ membrane, solid phase extraction, and injection onto the chromatographic column (as described in Section 2.3.1).

\subsubsection{Selectivity}

The selectivity of the method was evaluated by comparing the analyte retention times obtained for the samples and the standard solutions and by comparing the absorption spectra of the chromatographic peaks obtained for urine samples fortified with tt-MA standard with those for standard solutions of $t t$-MA prepared in water.

\subsubsection{Matrix Interferences}

Interferences caused by the presence of the biological matrix were assessed by comparing the coefficients of determination obtained for analytical curves constructed using aqueous standard solutions and standard solutions prepared using the pooled urine sample. The SPE extraction was performed under the optimized conditions. 


\subsubsection{Analytical Curve Adjustment and Working Range}

The analytical curve adjustment and working range of the method were evaluated using the determination coefficients $\left(R^{2}\right)$ obtained for the analytical curves constructed using the standards prepared in the pooled urine, in the concentration range $5-500 \mu \mathrm{g} \cdot \mathrm{L}^{-1}$.

\subsubsection{Limits of Detection and Quantification}

The limits of detection (LOD) and quantification (LOQ) of the method were determined using the average area of the baseline noise of several chromatograms obtained for the analysis of the pooled urine sample. The calculated LOD and LOQ concentration values were equivalent to 3- and 10-times the average area of the baseline noise, respectively.

\subsubsection{Precision and Accuracy}

The precision of the technique was measured using the coefficient of variation (CV) value obtained for repetitions of the entire procedure, from sample preparation up to injection onto the chromatographic column. Values of up to $20 \%$ are normally considered acceptable for analytical methods applied to environmental samples with complex matrices [48,49].

Accuracy was determined using the percentage recovery of $t t$-MA added to urine at concentrations of 5.0, 50 and $500 \mu \mathrm{g} \cdot \mathrm{L}^{-1}$, with nine replicates [48].

\section{Results and Discussion}

\subsection{Optimization of Sample Preparation}

Urine is a complex matrix that includes protein, salt, hormones, drugs and a variety of other compounds. Therefore, it is recommended that a pretreatment might be required in order to obtain a satisfactory chromatography performance. Qualitative tests of protein precipitation were performed using four systems: (1) pure sample; (2) sample with $0.01 \mathrm{~mol} \cdot \mathrm{L}^{-1}$ sulfuric acid; (3) sample with $0.01 \mathrm{~mol} \cdot \mathrm{L}^{-1}$ sulfuric acid and acetonitrile (65:35); and (4) $0.01 \mathrm{~mol} \cdot \mathrm{L}^{-1}$ sulfuric acid, used as a reference. All of the systems were kept at a temperature of $55{ }^{\circ} \mathrm{C}$ for $24 \mathrm{~h}$, for the observation of turbidity. However, no cloudiness was observed in any of the cases, and then it was adopted only passing the sample through a $0.22 \mu \mathrm{m}$ membrane.

A $2^{4-1}$ fractional factorial design with triplicate central points was used to optimize the extraction process, considering the following variables: sample buffering, remove of interferents, final volume and the volume of sample used in the extraction process. In the normal probability plot (Figure 2), point $\mathrm{C} 1$, corresponding to sample buffering, showed a large negative effect. Some of the previous studies reported in the literature used extraction without buffering $[27,30,36,38,41]$, while in other work concerning the exposure of humans to benzene, better analytical results were achieved by buffering of samples $[29,50,51]$.

The sample volume ( $\mathrm{C} 4$ in Figure 2) showed the greatest positive effect, indicating that the best extraction conditions were obtained using $3 \mathrm{~mL}$ of urine, which provided a greater quantity of urinary $t t$-MA. 


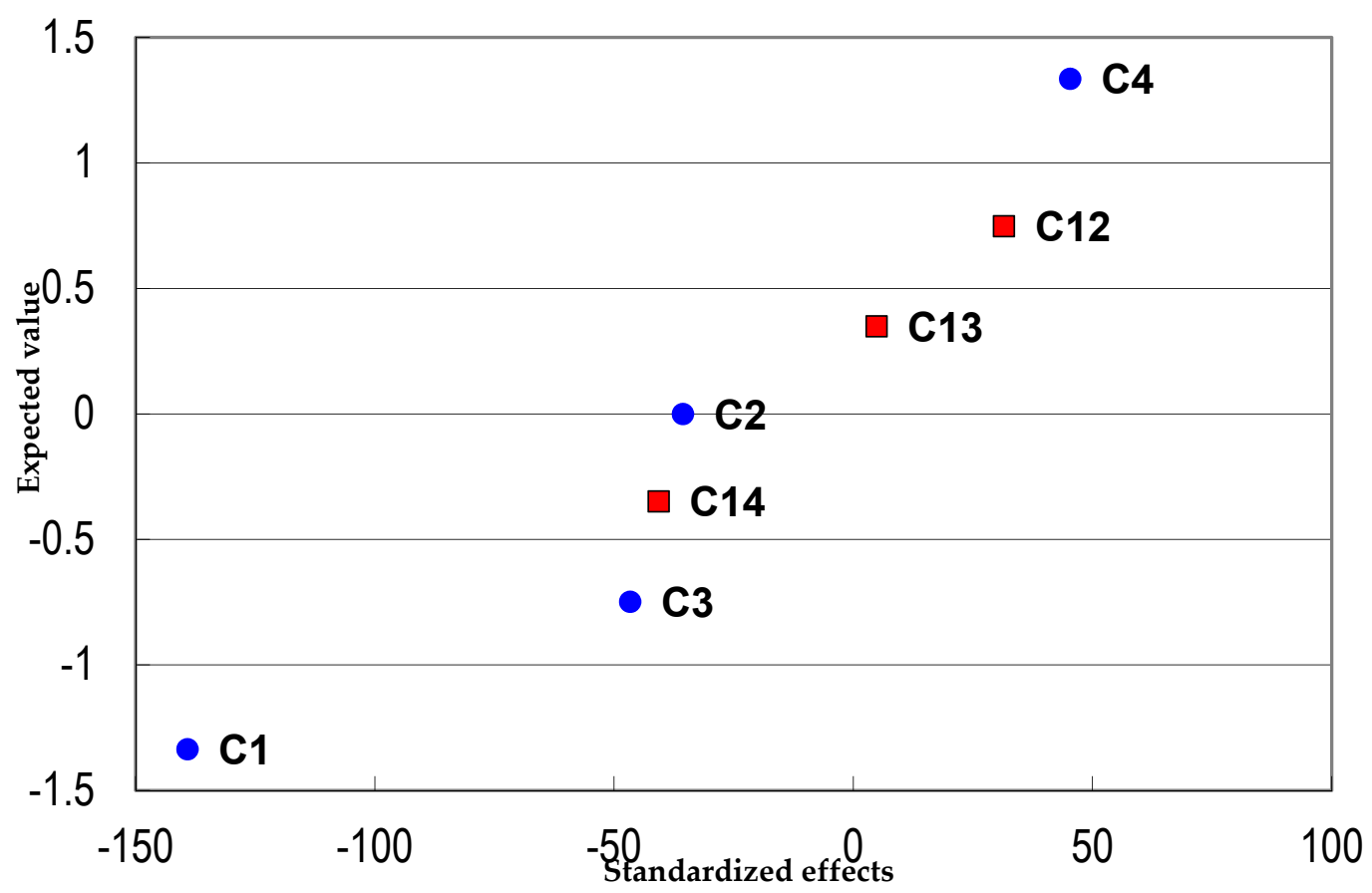

Figure 2. Normal probability plot showing the effects of sample buffering (C1), removal of interferents (C2), final volume (C3) and sample volume (C4).

In the fractional factorial design, the coefficient of variation of the tests was obtained by the analysis of the triplicate in the central point. The coefficient of variation of the signal obtained under the conditions was $1.95 \%$. The highest $t t$-MA peak areas were obtained for Test 5 , followed by Test 3 (Table 3).

Table 3. Optimization using the $2^{4-1}$ fractional factorial design. $X_{1}$ : buffering of sample; $X_{2}$ : removal of interferents; $X_{3}$ : final volume; $X_{4}$ : sample volume; $y$ : area of the $t t$-MA peak.

\begin{tabular}{|c|c|c|c|c|c|}
\hline Test & $X_{1}$ & $X_{2}$ & $X_{3}$ & $X_{4}$ & $y$ \\
\hline 1 & -1 & -1 & -1 & -1 & 106,519 \\
\hline 2 & 1 & -1 & -1 & 1 & 38,378 \\
\hline 3 & -1 & 1 & -1 & 1 & 116,419 \\
\hline 4 & 1 & 1 & -1 & -1 & 33,805 \\
\hline 5 & -1 & -1 & 1 & 1 & 124,593 \\
\hline 6 & 1 & -1 & 1 & -1 & 14,086 \\
\hline 7 & -1 & 1 & 1 & -1 & 44,460 \\
\hline 8 & 1 & 1 & 1 & 1 & 14,293 \\
\hline CP1 & 0 & 0 & 0 & 0 & 38,802 \\
\hline $\mathrm{CP} 2$ & 0 & 0 & 0 & 0 & 37,527 \\
\hline $\mathrm{CP} 3$ & 0 & 0 & 0 & 0 & 37,513 \\
\hline \multicolumn{5}{|c|}{$\mathrm{CP}$ (mean) } & 37,947 \\
\hline \multicolumn{5}{|c|}{$\mathrm{CP}$ (standard deviation) } & 740.2 \\
\hline \multicolumn{5}{|c|}{ CP (RSD, \%) } & 1.95 \\
\hline
\end{tabular}

Comparing the levels of four variables tested in the two best conditions, 3 and 5, we can see that variables that interfered more with the system of extraction, sample buffering $(\mathrm{C} 1)$ and sample volume (C4) have the same levels in these two tests, confirming that the other variables (C2 and C3) do not interfere with the system.

The optimized sample preparation conditions (Table 4) were used in all of the subsequent experiments. 
Table 4. Optimized sample preparation conditions.

\begin{tabular}{cc}
\hline Parameter & Condition \\
\hline Buffering & None \\
Sample volume & $3.0 \mathrm{~mL}$ \\
Sample washing & $5.0 \mathrm{~mL}$ of acetic acid $(1 \%)$ \\
Final volume & $5.0 \mathrm{~mL}$ of acetic acid $(10 \%)$ \\
\hline
\end{tabular}

\subsection{Evaluation of Analytical Conditions}

As shown in the results of the factorial design, the absence of buffering therefore provided the best analytical conditions. The first mobile phase used for the chromatographic separation of $t t-\mathrm{MA}$ was $0.01 \mathrm{~mol} \cdot \mathrm{L}^{-1}$ sulfuric acid. Other mobile phases tested were sulfuric acid at a concentration of $0.02 \mathrm{~mol} \cdot \mathrm{L}^{-1}$, as well as sulfuric acid solutions with the addition of an organic modifier (acetonitrile) at different ratios (65:35, 75:25, 85:15, 90:10 and 95:5). However, none of these mobile phases showed better performance than sulfuric acid at a concentration of $0.01 \mathrm{~mol} \cdot \mathrm{L}^{-1}$. Typical chromatograms obtained for the separation of $t t$-MA using this mobile phase at a flow rate of $0.6 \mathrm{~mL} \cdot \mathrm{min}^{-1}$ are shown in Figure 3.
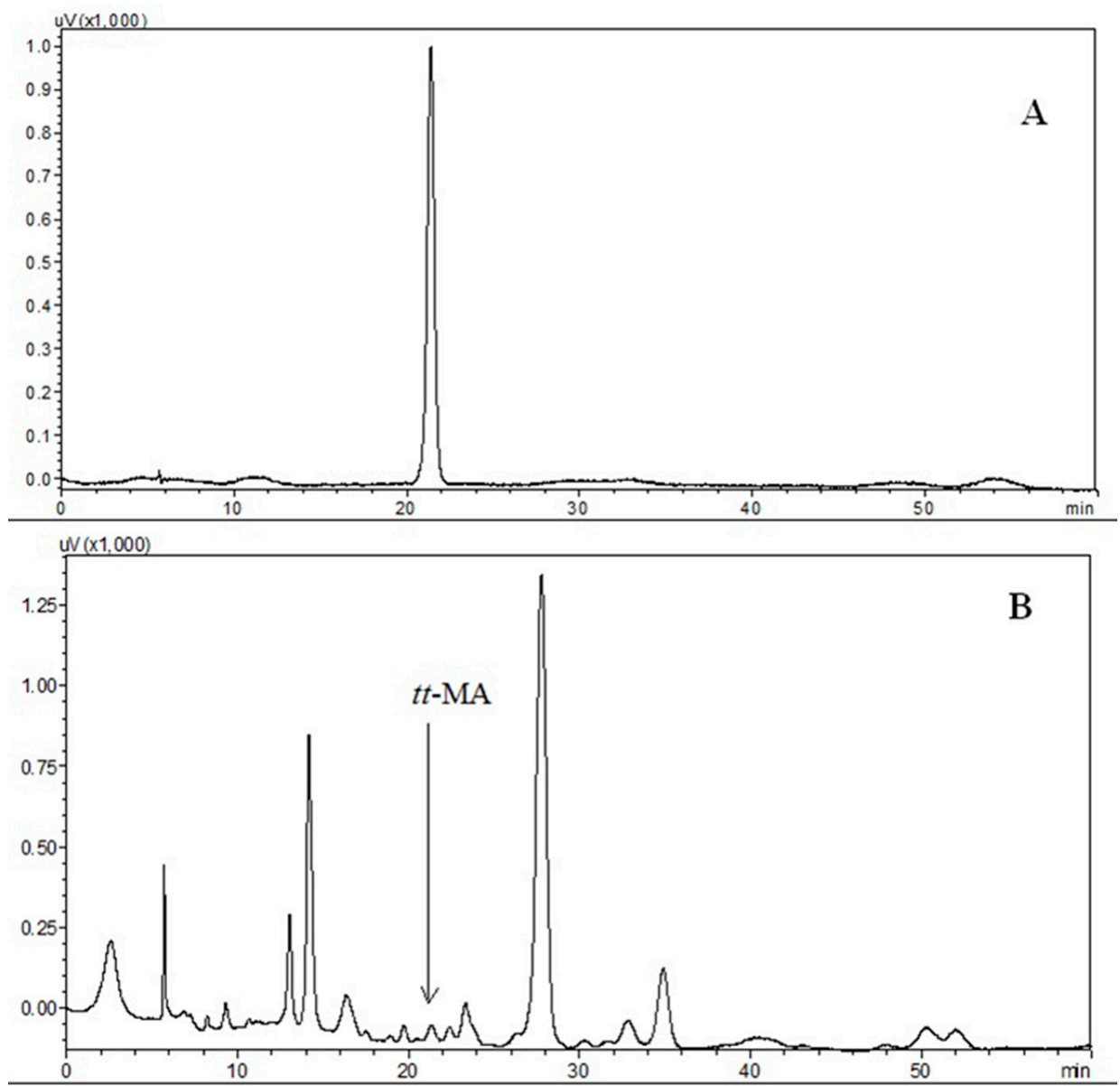

Figure 3. Chromatograms obtained for the separation of $t t$-MA using the Aminex $\mathrm{HPX}-87 \mathrm{H}$ (300 $\mathrm{mm} \times 7.8 \mathrm{~mm}$ ) ion exchange column with a mobile phase of $0.01 \mathrm{~mol} \cdot \mathrm{L}^{-1}$ sulfuric acid at a flow rate of $0.6 \mathrm{~mL} \cdot \mathrm{min}^{-1}$, detection by diode array detector (DAD) at $264 \mathrm{~nm}$. Chromatogram A: standard solution of $t t$-MA (500 $\left.\mu \mathrm{g} \cdot \mathrm{L}^{-1}\right)$; Chromatogram B: in natura urine sample. 


\subsection{Validation of the Method}

After optimization of the chromatographic conditions (summarized in Table 5) and the sample preparation procedure, the method was validated to ensure that it complied with established norms $[48,49,52]$.

Table 5. Optimized chromatographic conditions employed for the validation of the method for the determination of trans,trans-muconic acid.

\begin{tabular}{cc}
\hline Chromatographic Conditions & Description \\
\hline Column & Aminex HPX-87H $(300 \mathrm{~mm} \times 7.8 \mathrm{~mm})$ ion exclusion \\
Mobile phase flow rate & $0.6 \mathrm{~mL} \cdot \mathrm{min}^{-1}$ \\
Injection volume & $20 \mu \mathrm{L}$ (automatic injection system) \\
Column temperature & $55^{\circ} \mathrm{C}$ \\
Run time & $60 \mathrm{~min}$ \\
\hline
\end{tabular}

\subsubsection{Selectivity}

Since this work employed high performance liquid chromatography, the evaluation of the selectivity of the method employed the analyte retention times, comparing the retention times obtained for the in natura sample, standard solutions and fortified samples. A comparison was also made of the absorption diode array detector (DAD) spectra of the species eluted at the retention time of $t t$-MA in the sample chromatograms and the spectra obtained for the $t t$-MA standard solutions.

The presence of $t t$-MA peaks in the sample chromatograms was confirmed using four different techniques, depending on the level of uncertainty in the evaluation: (1) by comparing the retention time of the $t t$-MA peak in the sample chromatogram with the retention time of the peak obtained for a $t t$-MA standard, under the same conditions; (2) by the increase in the area of the peak resulting from the addition of $t t$-MA standard to the sample; (3) by comparison of the absorption spectrum of the $t t$-MA peak obtained for a standard solution with that of the peak obtained for the sample; and (4) according to the degree of purity of the eluted peak, as determined using the LabSolutions software, version 5.53 SP3 (Shimatzu, Laval, PQ, Canada). In the last case, the evaluation is made of the absorption spectra at the retention times corresponding to the upslope, top and downslope regions of the chromatographic peak, comparing them in order to identify any possibility of co-elution of other substances. The results of these different procedures applied to the chromatographic peaks showed that the method was selective to $t t$-MA.

\subsubsection{Interferences due to the Biological Matrix}

The analytical curve obtained using standards prepared in aqueous solution showed a slope (angular coefficient) that was greater than the slope of the curve for standards prepared in the pooled urine from the ten volunteers (all of whom were non-smokers with no history of occupational exposure to benzene). These results (Figure 4) indicated that the presence of the sample matrix depressed the analyte extraction efficiency by around 50\% (Equation (1)), resulting in a decrease in sensitivity. Despite the existence of matrix interferences, this is not a problem, since all of the analytical curves used for the quantification of $t t-\mathrm{MA}$ in urine samples were constructed using standards prepared in the pooled urine.

$$
\text { Matrix effect }(\%)=\frac{X_{1}}{X_{2}} \times 100
$$

where:

$X_{1}: t t$-MA peak area for the analytical curve prepared using aqueous standards; $X_{2}$ : $t t$-MA peak area for the analytical curve prepared using pooled urine. 


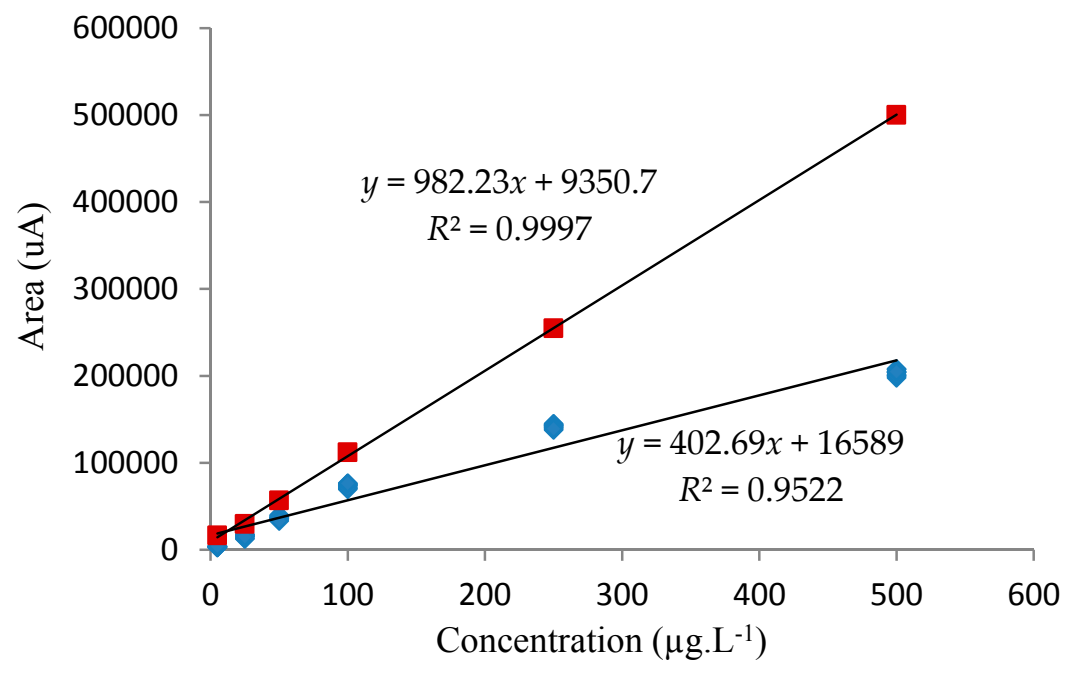

Figure 4. Analytical curves obtained for the determination of trans,trans-muconic acid in urine. The square red and blue points correspond to the values obtained for standards prepared in aqueous solution and pooled urine, respectively.

\subsubsection{Analytical Curve Adjustment and Working Range}

A coefficient of determination $\left(R^{2}\right)$ value exceeding 0.99 was obtained for linear fitting of the analytical curve prepared using aqueous $t t$-MA standards in the concentration range $5-500 \mu \mathrm{g} \cdot \mathrm{L}^{-1}$. An $R^{2}$ value of 0.98 was obtained for linear fitting of the curve prepared using standards prepared in the pooled urine at concentrations in the range $5-250 \mu \mathrm{g} \cdot \mathrm{L}^{-1}$, while a quadratic fit with an $R^{2}$ value exceeding 0.99 was obtained for standards prepared in the pooled urine at concentrations in the range 5-500 $\mu \mathrm{g} \cdot \mathrm{L}^{-1}$ (Figure 5). These results were in accordance with established norms and were considered satisfactory $[48,52]$.

The concentrations used to determine the working range were based on $t t$-MA concentrations reported in the literature [42,50]. The results showed that linear fits (determination coefficient, $R^{2}=0.9909$ ) could be applied to analytical curves prepared using concentrations of $t t$-MA in urine up to $100 \mu \mathrm{g} \cdot \mathrm{L}^{-1}$. At higher concentrations (up to $500 \mu \mathrm{g} \cdot \mathrm{L}^{-1}$ ), a quadratic fit (determination coefficient, $R^{2}=0.9982$ ) could be used, or the samples could be diluted after the extraction step, in order to use the linear model.

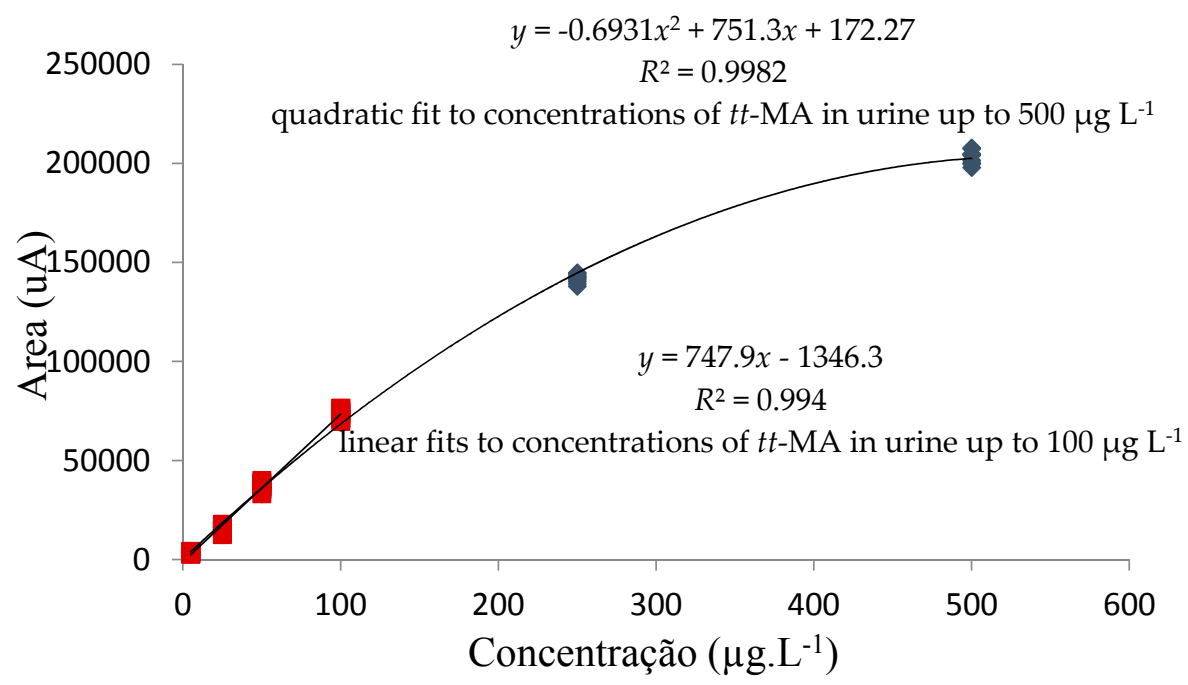

Figure 5. Analytical curves constructed using standards (nine replicates) prepared in pooled urine. 


\subsubsection{Limits of Detection and Quantification}

The limits of detection (LOD) and quantification (LOQ) of the method were calculated using the signal-to-noise ratio, as described previously. The values obtained were $0.11 \mu \mathrm{g} \cdot \mathrm{L}^{-1}$ (LOD) and $0.36 \mu \mathrm{g} \cdot \mathrm{L}^{-1}$ (LOQ).

\subsubsection{Precision and Accuracy}

The precision of the method was determined from the intra-experiment repeatability, considering the $t t$-MA concentrations obtained for one sample extract that was analyzed seven times on the same day. No evaluation was made of inter-experiment repeatability (analyses on different days). The results were calculated as coefficient of variation (CV) values (Table 6). The highest value obtained was $1.47 \%$, demonstrating that the method provided good precision. The results also showed that the precision was independent of the amount of $t t$-MA present in the sample. Although the intermediate precision was not determined, the results indicated that there was little variation for the measurements made on different days or by different analysts.

Table 6. Coefficients of variation (CV) for the determination of $t t-\mathrm{MA}$ in the pooled urine sample and in pooled urine enriched with $t t$-MA at concentrations of 5.0, 50.0 and $500.0 \mu \mathrm{g} \cdot \mathrm{L}^{-1}$, using nine replicates $(n=9)$.

\begin{tabular}{ccc}
\hline Urine Sample & Average Peak Area $(\mu \mathrm{A})$ & $\mathrm{CV}(\mathbf{\%})$ \\
\hline Pool of 10 samples & 96,461 & 1.22 \\
Pool with addition of $5.0 \mu \mathrm{g} \cdot \mathrm{L}^{-1}$ & 99,892 & 0.53 \\
Pool with addition of $50.0 \mu \mathrm{g} \cdot \mathrm{L}^{-1}$ & 133,092 & 1.47 \\
Pool with addition of $500 \mu \mathrm{g} \cdot \mathrm{L}^{-1}$ & 299,546 & 1.16 \\
\hline
\end{tabular}

The accuracy of the method was determined using the recovery of $t t$-MA standards added to the pooled urine at concentrations of 5.0, 50.0 and $500.0 \mu \mathrm{g} \cdot \mathrm{L}^{-1}$. The concentration of $t t-\mathrm{MA}$ in the unfortified pooled urine was $88.6 \mu \mathrm{g} \cdot \mathrm{L}^{-1}$, calculated using the linear equation describing the analytical curve constructed using aqueous standards.

The concentrations of $t t$-MA quantified in the fortified urine samples using the quadratic equation describing the analytical curve constructed using standards prepared in the pooled urine represented recoveries close to $100 \%$ (Table 7), with the exception of the sample fortified with $5.0 \mu \mathrm{g} \cdot \mathrm{L}^{-1} \mathrm{of} t t-\mathrm{MA}$, for which a recovery of $87.20 \%$ was obtained. The lower recovery found for an added concentration of $5 \mu \mathrm{g} \cdot \mathrm{L}^{-1}$ can be explained by the fact that the concentration of $t t-\mathrm{MA}$ already present in the urine $\left(88.6 \mu \mathrm{g} \cdot \mathrm{L}^{-1}\right)$ was much higher than the amount added. Ideally, the additions of $t t$-MA standard should be made to samples of urine containing lower levels of the analyte. However, it is impossible to obtain a priori knowledge of the concentrations of $t t$-MA in pooled urine samples. Despite the fact that the samples used here were obtained from volunteers for whom low concentrations of $t t$-MA were expected, metabolic differences between individuals contribute to uncertainty.

Table 7. Recoveries obtained for quantification using the analytical curve constructed using standards prepared in the pooled urine from ten non-smoker volunteers. Amounts of $t t$-MA standard equivalent to concentrations of $5.0,50.0$ and $500.0 \mu \mathrm{g} \cdot \mathrm{L}^{-1}$ were added to pooled urine with a $t t$-MA content of $88.6 \mu \mathrm{g} \cdot \mathrm{L}^{-1}(n=9)$.

\begin{tabular}{ccc}
\hline Concentration of $\boldsymbol{t} t$-MA Added $\left(\boldsymbol{\mu} \mathbf{g} \cdot \mathbf{L}^{-\mathbf{1}}\right)$ & Concentration of $\boldsymbol{t} \boldsymbol{t}$-MA Found $\left(\boldsymbol{\mu g} \cdot \mathbf{L}^{-\mathbf{1}}\right)$ & Recovery $(\%)$ \\
\hline 5.0 & 4.4 & 87.20 \\
50.0 & 50.9 & 101.84 \\
500.0 & 510.6 & 102.12 \\
\hline
\end{tabular}


Although the quantification of urinary $t t$-MA using analytical curves constructed employing standards prepared in the pooled urine made the method more labor-intensive, the accuracy was much improved. In the case of analytical methods involving complex matrices, such as urine, recovery values in the range $80 \%-120 \%$ are acceptable [49,52]. The results obtained here could therefore be considered satisfactory. Although the analysis time was higher in these proposed conditions than using reverse phase, the results obtained here could therefore be considered satisfactory because the separation of the different compounds, particularly $t t$-muconic acid, was well performed by a combination of different mechanisms: hydrophobicity, size exclusion and ion exclusion. Thus, the chromatographic resolutions were much better, allowing a separation of $t t$-muconic acid at baseline without interference.

\section{Conclusions}

The method, not yet described in the literature, was optimized and validated for the determination of urinary $t t-\mathrm{MA}$, using solid phase extraction with Strata SAX cartridges and chromatographic separation with an Aminex HPX 87H column. This method presented low limits of detection and quantification $\left(0.11\right.$ and $0.36 \mu \mathrm{g} \cdot \mathrm{L}^{-1}$, respectively) and better resolution compared to other techniques described in the literature.

Acknowledgments: The authors thank Federal University of Ouro Preto (UFOP), National Counsel of Technological and Scientific Development (CNPq) _financing 47983/2013-3 and Research Support Foundation of the State of Minas Gerais (FAPEMIG) - financing APQ 00918-13.

Author Contributions: Rafaela de Paiva Gomes participated in the research as an undergraduate student, and his research project was led by Mauricio Xavier Coutrim. The other authors, Ananda Lima Sanson, Fabiana Aparecida Lobo and Robson Jose de Cassia Franco Afonso, were collaborators in the development of the project at various stages of research.

Conflicts of Interest: The authors declare no conflict of interest.

\section{References}

1. Protano, C.; Andreoli, R.; Manini, P.; Guidotti, M.; Vitali, M. A tobacco-related carcinogen: Assessing the impact of smoking behaviours of cohabitants on benzene exposure in children. Tob. Control 2012, 21, 325-329. [CrossRef] [PubMed]

2. Guarieiro, L.L.N.; Vasconcellos, P.C.; Solci, M.C. Air Pollutants from the burning of fossil fuels and biofuels: A brief review. Rev. Virtual Quim. 2011, 3, 434-445. [CrossRef]

3. Manini, P.; de Palma, G.; Andreoli, R.; Poli, D.; Mozzoni, P.; Folesani, G.; Mutti, A.; Apostoli, P. Environmental and biological monitoring of benzene exposure in a cohort of Italian taxi drivers. Toxicol. Lett. 2006, 167, 142-151. [CrossRef] [PubMed]

4. Kivistö, H.; Pekari, K.; Peltonen, K.; Svinhufvud, J.; Veidebaum, T.; Sorsa, M.; Aitio, A. Biological monitoring of exposure to benzene in the production of benzene and in a cokery. Sci. Total Environ. 1997, 199, 49-63. [CrossRef]

5. Choi, Y.; Shin, D.; Park, S.; Chung, Y.; Kim, M. Biological monitoring of benzene in residents living near petrochemical industrial areas in Korea. J. Occup. Health 2000, 42, 31-37. [CrossRef]

6. Kirkeleit, J.; Riise, T.; Bråtveit, M.; Pekari, K.; Mikkola, J.; Moen, B.E. Biological monitoring of benzene exposure during maintenance work in crude oil cargo tanks. Chem.-Biol. Interact. 2006, 164, 60-67. [CrossRef] [PubMed]

7. Brugnone, F.; Perbellini, L.; Maranelli, G.; Romeo, L.; Guglielmi, G.; Lombardini, F. Reference values for blood benzene in the occupationally unexposed general population. Int. Arch. Occup. Environ. Health 1992, 64, 179-184. [CrossRef]

8. Aprea, C.; Sciarra, G.; Bozzi, N.; Pagliantini, M.; Perico, A.; Bavazzano, P.; Leandri, A.; Carrieri, M.; Scapellato, M.; Bettinelli, M.; et al. Reference Values of Urinary trans,trans-muconic Acid: Italian Multicentric Study. Arch. Environ. Contam. Toxicol. 2008, 55, 329-340. [CrossRef] [PubMed]

9. Fustinoni, S.; Campo, L.; Mercadante, R.; Manini, P. Methodological issues in the biological monitoring of urinary benzene and S-phenylmercapturic acid at low exposure levels. J. Chromatogr. B 2010, 878, 2534-2540. [CrossRef] [PubMed] 
10. Waidyanatha, S.; Rothman, N.; Fustinoni, S.; Smith, M.T.; Hayes, R.B.; Bechtold, W.; Dosemeci, M.; Guilan, L.; Yin, S.; Rappaport, S.M. Urinary benzene as a biomarker of exposure among occupationally exposed and unexposed subjects. Carcinogenesis 2001, 22, 279-286. [CrossRef] [PubMed]

11. Coutrim, M.X.; de Carvalho, L.R.F.; Arcuri, A.S.A. Evaluation of the analytical methods to determinate benzene metabolites as potencial biomarkers for determining human exposure to benzene in air. Quim. Nova 2000, 23, 653-663. [CrossRef]

12. Ministry of Labor and Employment of Brazil. Portaria No. 34, 20 December 2001, Attachment: Protocolo para a Utilização de Indicador Biológico da Exposição Ocupacional ao Benzeno. Available online: http: //www.capecanaveral4045.com/legislacao/port_34_2001_benzeno_indicador_biologico.html (accessed on 12 September 2015).

13. Menezes, M.; Balbão, M.S.; Siqueira, M.E.P.B.; Martins, I. Influence of tobacco smoking on urinary excretion of trans,trans-muconic acid. Braz. J. Pharm. Sci. 2008, 44, 459-464.

14. Roma-Torres, J.; Teixeira, J.P.; Silva, S.; Laffon, B.; Cunha, L.; Mendez, J.; Mayan, O. Evaluation of genotoxicity in a group of workers from a petroleum refinery aromatics plant. Mutat. Res. 2006, 604, 19-27. [CrossRef] [PubMed]

15. Violante, F.; Sanguinetti, G.; Barbieri, A.; Accorsi, A.; Mattioli, S.; Cesari, R.; Fimognari, C.; Hrelia, P. Lack of correlation between environmental or biological indicators of benzene exposure at parts per billion levels and micronuclei induction. Environ. Res. 2003, 91, 135-142. [CrossRef]

16. Kouniali, A.; Cicolella, A.; Gonzalez-Flesca, N.; Dujardin, R.; Gehanno, J.-F.; Bois, F.Y. Environmental benzene exposure assessment for parent-child pairs in Rouen. France. Sci. Total Environ. 2003, 308, 73-82. [CrossRef]

17. Cocco, P.; Tocco, M.G.; Ibba, A.; Scano, L.; Ennas, M.G.; Flore, C.; Randaccio, F. trans,trans-Muconic acid excretion in relation to environmental exposure to benzene. Int. Arch. Occup. Environ. Health 2003, 76, 456-460. [CrossRef] [PubMed]

18. Marrubini, G.; Coccini, T.; Manzo, L. Direct analysis of urinary trans,trans-muconic acid by coupled column liquid chromatography and spectrophotometric ultraviolet detection: Method applicability to human urine. J. Chromatogr. B 2001, 758, 295-303. [CrossRef]

19. Waidyanatha, S.; Rothman, N.; Li, G.; Smith, M.T.; Yin, S.; Rappaport, S.M. Rapid determination of six urinary benzene metabolites in occupationally exposed and unexposed subjects. Anal. Biochem. 2004, 327, 184-199. [CrossRef] [PubMed]

20. Kim, S.; Vermeulen, R.; Waidyanatha, S.; Johnson, B.A.; Lan, Q.; Rothman, N.; Smith, M.T.; Zhang, L.; Li, G.; Shen, M.; et al. Using urinary biomarkers to elucidate dose-related patterns of human benzene metabolism. Carcinogenesis 2006, 27, 772-781. [CrossRef] [PubMed]

21. Mudiam, M.K.R.; Chauhan, A.; Singh, K.P.; Gupta, S.K.; Jain, R.; Ch, R.; Murthy, R.C. Determination of $t, t$-muconic acid in urine samples using a molecular imprinted polymer combined with simultaneous ethyl chloroformate derivatization and pre-concentration by dispersive liquid-liquid microextraction. Anal. Bioanal. Chem. 2013, 405, 341-349. [CrossRef] [PubMed]

22. Sørensen, M.; Skov, H.; Autrup, H.; Hertel, O.; Loft, S. Urban benzene exposure and oxidative DNA damage: Influence of genetic polymorphisms in metabolism genes. Sci. Total Environ. 2003, 309, 69-80. [CrossRef]

23. Wiwanitkit, V.; Suwansaksri, J.; Soogarun, S. A note on urine trans, trans muconic acid level among a sample of Thai police: Implication for an occupational health issue. Yale J. Biol. Med. 2003, 76, 103-108. [PubMed]

24. Ruppert, T.; Scherer, G.; Tricker, A.R.; Rauscher, D.; Adlkofer, F. Determination of urinary trans,trans-muconic acid by gas chromatography-mass spectrometry. J. Chromatogr. B 1995, 666, 71-76. [CrossRef]

25. Franqui, L.S.; Vieira, A.C.; Maia, P.P.; Figueiredo, E.C. Molecularly imprinted solid-phase extraction of urinary trans,trans-muconic acid and analysis by gas chromatography-mass spectrometry. Quím. Nova 2012, 35, 1577-1581. [CrossRef]

26. Johnson, E.S.; Langård, S.; Lin, Y.-S. A critique of benzene exposure in the general population. Sci. Total Environ. 2007, 374, 183-198. [CrossRef] [PubMed]

27. Ducos, P.; Gaudin, R.; Robert, A.; Francin, J.; Maire, C. Improvement in HPLC analysis of urinary trans,trans-muconic acid, a promising substitute for phenol in the assessment of benzene exposure. Int. Arch. Occup. Environ. Health 1990, 62, 529-534. [CrossRef] [PubMed]

28. Negri, S.; Bono, R.; Maestri, L.; Ghittori, S.; Imbriani, M. High-pressure liquid chromatographic-mass spectrometric determination of sorbic acid in urine: Verification of formation of trans,trans-muconic acid. Chem.-Biol. Interact. 2005, 153, 243-246. [CrossRef] [PubMed] 
29. Schroijen, C.; Baeyens, W.; Schoeters, G.; den Hond, E.; Koppen, G.; Bruckers, L.; Nelen, V.; van de Mieroop, E.; Bilau, M.; Covaci, A.; et al. Internal exposure to pollutants measured in blood and urine of Flemish adolescents in function of area of residence. Chemosphere 2008, 71, 1317-1325. [CrossRef] [PubMed]

30. Serena, P.; Tapparo, A.; Bombi, G. Direct determination of $t, t$-muconic acid in human urine by two-dimensional liquid chromatography. Analyst 2000, 125, 689-692. [CrossRef] [PubMed]

31. Melikian, A.A.; Connor, R.; Prahalad, A.; Hu, P.; Li, H.; Kagan, M.; Thompson, S. Determination of the urinary benzene metabolites $S$-phenylmercapturic acid and trans,trans-muconic acid by liquid chromatography-tandem mass spectrometry. Carcinogenesis 1999, 20, 719-726. [CrossRef] [PubMed]

32. Senzolo, C.; Frignani, S.; Pavoni, B. Environmental and biological monitoring of occupational exposure to organic micropollutants in gasoline. Chemosphere 2001, 44, 67-82. [CrossRef]

33. Barbieri, A.; Sabatini, L.; Accorsi, A.; Roda, A.; Violante, F. Simultaneous determination of $t, t$-muconic, $S$-phenylmercapturic and $S$-benzylmercapturic acids in urine by a rapid and sensitive liquid chromatography/electrospray tandem mass spectrometry method. Rapid Commun. Mass Spectrom. 2004, 18, 1983-1988. [CrossRef] [PubMed]

34. Manini, P.; Andreoli, R.; Niessen, W.M.A. Liquid chromatography-mass spectrometry in occupational toxicology: A novel approach to the study of biotransformation of industrial chemicals. J. Chromatogr. A 2004, 1058, 21-37. [CrossRef]

35. Fustinoni, S.; Buratti, M.; Campo, L.; Colombi, A.; Consonni, D.; Pesatori, A.C.; Bonzini, M.; Farmer, P.; Garte, S.; Valerio, F.; et al. Urinary $t, t$-muconic acid, $S$-phenylmercapturic acid and benzene as biomarkers of low benzene exposure. Chem.-Biol. Interact. 2005, 153, 253-256. [CrossRef] [PubMed]

36. Lee, B.; Ong, H.; Ong, Y.; Ong, C. A sensitive liquid chromatographic method for the spectrophotometric determination of urinary trans,trans-muconic acid. J. Chromatogr. B 2005, 818, 277-283. [CrossRef] [PubMed]

37. Navasumrit, P.; Chanvaivit, S.; Intarasunanont, P.; Arayasiri, M.; Lauhareungpanya, N.; Parnlob, V.; Settachan, D.; Ruchirawat, M. Environmental and occupational exposure to benzene in Thailand. Chem.-Biol. Interact. 2005, 153, 75-83. [CrossRef] [PubMed]

38. Carrieri, M.; Bonfiglio, E.; Scapellato, M.L.; Maccà, I.; Tranfo, G.; Faranda, P.; Paci, E.; Bartolucci, G.B. Comparison of exposure assessment methods in occupational exposure to benzene in gasoline filling-station attendants. Toxicol. Lett. 2006, 162, 146-152. [CrossRef] [PubMed]

39. Scherer, G.; Engl, J.; Urban, M.; Gilch, G.; Janket, D.; Riedel, K. Relationship between machine-derived smoke yields and biomarkers in cigarette smokers in Germany. Regul. Toxicol. Pharm. 2007, 47, 171-183. [CrossRef] [PubMed]

40. Ray, M.; Roychoudhury, S.; Mukherjee, S.; Lahiri, T. Occupational benzene exposure from vehicular sources in India and its effect on hematology, lymphocyte subsets and platelet P-selectin expression. Toxicol. Ind. Health 2007, 23, 167-175. [CrossRef] [PubMed]

41. Chakroun, R.; Faidi, F.; Hedhili, A.; Charbaji, K.; Nouaigui, H.; Laiba, M.B. Inhalant Abuse Detection and Evaluation in Young Tunisians. J. Forensic Sci. 2008, 53, 232-237. [CrossRef] [PubMed]

42. Weaver, V.; Buckley, T.; Groopman, J.D. Lack of specificity of trans,trans-muconic acid as a benzene biomarker after ingestion of sorbic acid-preserved foods. Cancer Epidemiol. Biomarkers Prev. 2000, 9, 749-755. [PubMed]

43. Fritz, J.S. Review: Principles and applications of ion-exclusion chromatography. J. Chromatogr. 1991, 546, 111-118. [CrossRef]

44. Kelebek, H.; Selli, S. Determination of volatile, phenolic, organic acid and sugar components in a Turkish cv. Dortyol (Citrus sinensis L. Osbeck) orange juice. J. Agric. Food Chem. 2011, 91, 1855-1862. [CrossRef] [PubMed]

45. Eyeghe-Bickong, H.; Alexandersson, E.O.; Gouws, L.; Young, P.; Vivier, M.A. Optimisation of an HPLC method for the simultaneous quantification of the major sugars and organic acids in grapevine berries. J. Chromatogr. B 2012, 885, 43-49. [CrossRef] [PubMed]

46. Jeon, J.; Brigham, C.J.; Kim, Y.; Kim, H.; Yi, D.; Kim, H.; Rha, C.; Sinskey, A.; Yang, Y. Biosynthesis of poly(3-hydroxybutyrate-co-3-hydroxyhexanoate) ( $\mathrm{P}(\mathrm{HB}-c o-\mathrm{HHx})$ ) from butyrate using engineered Ralstonia eutropha. Appl. Microbiol. Biotech. 2014, 98, 5461-5469. [CrossRef] [PubMed]

47. Teófilo, R.F.; Ferreira, M.M.C. Chemometrics II: Spreadsheets for experimental design calculations, a tutorial. Quim. Nova 2006, 29, 338-350. [CrossRef] 
48. Brazil, National Institute of Metrology (INMETRO). Orientação Sobre Validação de Métodos Analíticos, 3rd Review, February 2010. Available online: http://www.inmetro.gov.br/sidoq/arquivos/cgcre/doq/ doq-cgcre-8_03.pdf (accessed on 14 September 2015).

49. Ribani, M.; Bottoli, C.B.G.; Collins, C.H.; Jardim, I.C.S.F.; Melo, L.F.C. Validation for chromatographic and electrophoretic methods. Quim. Nova 2004, 27, 771-780. [CrossRef]

50. Martins, I.; Siqueira, M.E.P.B. Determination of trans,trans-muconic acid in urine: Validation of a high performance liquid chromatographic method. Braz. J. Pharmac. Sci. 2002, 38, 205-213.

51. Tranfo, G.; Paci, E.; Sisto, R.; Pigini, D. Validation of an HPLC/MS/MS method with isotopic dilution for quantitative determination of trans,trans-muconic acid in urine samples of workers exposed to low benzene concentrations. J. Chromatogr. B 2008, 867, 26-31. [CrossRef] [PubMed]

52. Brazilian National Health Surveillance Agency (ANVISA). Resolution RE No. 899, 29 May 2003, Attachment: Guia para Validação de Métodos Analíticos e Bioanalíticos, pp. 56-59. Available online: http:/ / pesquisa.in.gov.br/ imprensa/jsp/visualiza/index.jsp?data=02/06/2003\&jornal=1\&pagina=56\&totalArquivos=176 (accessed on 14 September 2015).

(C) 2016 by the authors; licensee MDPI, Basel, Switzerland. This article is an open access article distributed under the terms and conditions of the Creative Commons Attribution (CC-BY) license (http://creativecommons.org/licenses/by/4.0/). 